\title{
J. B. S. Haldane, as I knew him
}

\author{
N. A. MITCHISON* \\ Division of Biosciences, Faculty of Life Sciences, University College London, London WC1E 6BT, UK \\ *E-mail: n.mitchison@ucl.ac.uk.
}

Published online 24 November 2017

Keywords. University College London; Haldane; Helen Spurway.

Growing up in London before the War, I met my uncle JBS as he was called, occasionally, and got to know him better when occasionally he visited Carradale, our family house in Scotland. In my youth, I had known him through my grandparents in Oxford, where they lived in a large house attached to a small estate. So it was natural that I should ask him to find employment for me in 1945 at University College London (UCL) where he worked, during my year between leaving school and going up to New College at Oxford University. He kindly did so.

That was the quiet last year of the war, while the university world in London was moving from wartime quiescence to rebuilding in preparation for the coming peace and the return of students. JBS found me a little job as a 'college servant', helping to prepare histology slides for the science and medical students due to arrive after the war. At that time Helen Spurway and JBS were happily married and lived in a north London flat. Helen worked on Drosophila genetics along with one or two colleagues in an annex, the 'fly house'. The idea was that she counted the Drosophila flies, and JBS then calculated their statistical significance (no computers in those days). Science in London at that time was much enriched by a diversity of refugees. Faberge, for instance, a scion of the great Tsarist jewellers, was constructing a bee counting machine, and he taught me to draw on London jeweller's equipment (we wanted to inject Drosophila larvae, in search of cytoplasmic inheritance), and there were other fascinating colleagues: notably M. J. D. White, who collected interesting larvae from under the bark of trees that he had felled a few nights previously.

JBS was busy, sitting in his office running the Journal of Genetics, which he had taken on; he read manuscripts and made genetic calculations as well as continuing his old habit of writing stories for publication in the Daily Worker, as well as writing his major book; he also delivered a series of lectures on genetics to a small band of students who turned up like me, as the war ended.

Helen Spurway was kind to me. She listened to what little I had to say, and she introduced me to the pub-crawl. Her crawl started in a pub just outside UCL's backgate, where many decades later 'The Professor's Chair' (where JBS sat) still resided. For me the crawl was highly educational (and great fun), as Helen explained to me how the world worked. In retrospect I fear it helped develop Helen's addiction, which became one of the many reasons for their migration to India.

The sad story of that migration is well known: the cancer which JBS was led to believe had been cured, the final trial of traditional medicine, the moves around in India. As his end approached, he saw The Journal of Genetics as a means of financial support for Helen after his death. The success of that elegant, successful and learned journal remains in my mind as a memorial to their lives and their love. I have just submitted what is surely my last paper to that journal, and found there a note that provides a clear and accurate account of its history and part played by Helen Spurway and JBS. What a delightful memorial! 